\title{
Accounting Practice and Intelligent Technologies
}

\author{
Daniela Postolache (Males), Phd. Student, „Alexandru Ioan Cuza” University of Iasi, \\ Romania
}

\begin{abstract}
Our paper presents current theoretical delimitations concerning intelligent technologies. Our objective was to determine how intelligent technologies can support accounting practice. Our research allowed for establishment of accounting information intelligent systems typology and for placement of these solutions in the sphere of artificial intelligence applications. It is underlined the intelligent technologies contribution to improve accounting processes and activities, in a qualitative approach, from the hermeneutic perspective.

The results of our research are useful for researchers in the fields of applied accounting, intelligent systems for accounting, information technology management. Also, our study is useful in the activity of accounting experts, given the presentation of new technologies used in their area of interest.
\end{abstract}

\section{Keywords}

accounting intelligent systems, accounting informational system, IT management, intelligent informational systems

\section{JEL Codes: D80, M41, M15, O33}

\section{Introduction}

Among the many theoretical approaches and definitions of the concept of accounting, we consider as very actual the perspective shared by Pauline Weetman, professor of accounting at the University of Edinburgh, according to which, accounting is the process of identification, measurement and communication of financial information about a particular entity, in order to facilitate informed decisions and opinions to users ${ }^{1}$.

Accounting must be understood as a set of aggregated knowledge (information), based on principles and postulates verified by economic practice ${ }^{2}$.

In the view of the C.S. Warren, J. M. Reeve and J. Duchac ${ }^{3}$ (2012), accounting can be defined as an information system that provides users with reports on economic activities and on conditions of running a business. The authors determined the information cycle through the accounting information system, composed of five stages, as shown in Figure 1.

It is not by chance that the central figure, in the accounting information system, is a computer image.

It is recognized that organizations use information technology to counteract to constraints effects established by various social, legal, economic, material and political factors.

\footnotetext{
${ }^{1}$ Weetman, P. (2006), Financial accounting: an introduction, 4th edition, Pearson Education Ltd., Harlow, UK, p. 19

${ }^{2}$ Horomnea, E. (2008), Fundamente ştiințifice ale contabilităţii.Doctrină.Concepte.Lexicon., Tipografia Moldova Publishing House, Iasi, p. 103

${ }^{3}$ Warren, C.S., Reeve J.M., Duchac, J. (2012),Accounting, 24th edition, Cengage Learning, Mason, USA, p. 3
} 


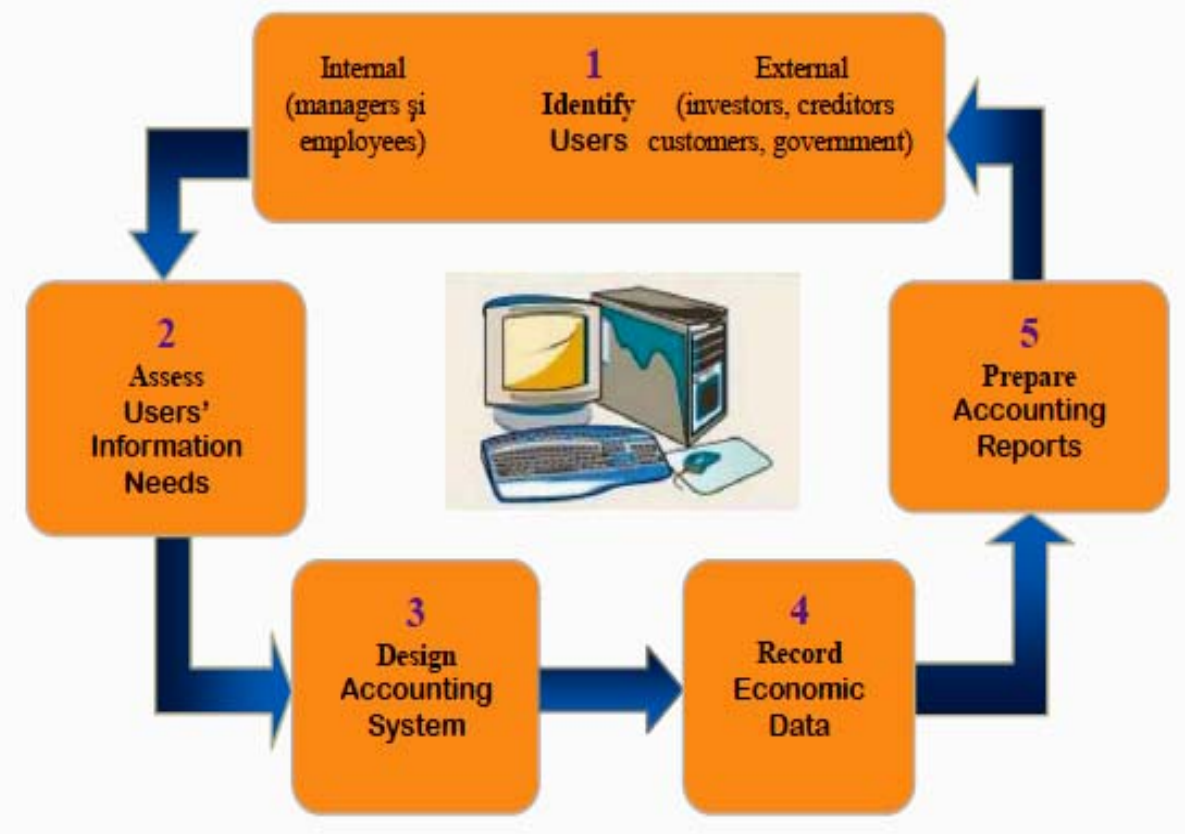

Figure 1. Accounting as an information system

Source: C.S. Warren, J.M. Reeve, J. Duchac, (2012),Accounting, 24th ed., Cengage Learning, Mason, USA, p.3

In the their paper, Introduction to Information Systems: Enabling and Transforming Business $^{4}$ Rainer, K. and Cegielski, C.G., set the constraints affecting the economic environment and the way organizations react to them, using information technology (IT), as shown in Table 1. We can consider this as a detail view of one half of a SWOT analysis: threats and opportunities. Solution and also opportunities available to organizations to counter threats as excessive accumulation of information and obsolescence, in the context of fast-paced technological innovation, ar given by the intelligent management of data and information, through intelligent technologies and intelligent informational systems.

\section{Intelligent accounting information system}

According to Negnevitsky ${ }^{5}$, technologies can be considered as "intelligent" when they are able to achieve human level of performance in some aspects of knowledge processing. In his book, A philosophical and mathematical dictionary ${ }^{6}$ (1815), the English mathematician Charles Hutton explains the meaning of the term solution: an answer or a resolution to an existing problem.

\footnotetext{
${ }^{4}$ Rainer, K., Cegielski C. G. (2011), Introduction to Information Systems: Enabling and Transforming Business, 3rd edition, John Wiley \& Sons, Inc., New Jersey, p.16

${ }^{5}$ Negnevitsky, M. (2005), Artificial intelligence: a guide to intelligent systems, 2nd edition, Pearson Education Ltd., Harlow, UK, p.4

${ }^{6}$ Hutton, C. (1815), A philosophical and mathematical dictionary, Vol. II, Printed by S. Hamilton, Weybridge, Surrey, London, p. 412
} 
Table 1. Ways to counter constraints using information and communication technologies

\begin{tabular}{|c|c|c|c|}
\hline $\begin{array}{c}\text { Influential factors } \\
\text { typology }\end{array}$ & $\begin{array}{c}\text { Constraints on the } \\
\text { economic } \\
\text { environment }\end{array}$ & Counter way & Used tool \\
\hline \multirow{7}{*}{ Societal/Legal/Political } & \multirow[t]{2}{*}{ Social responsibility } & $\begin{array}{c}\text { On-demand } \\
\text { made-to-order mass } \\
\text { customization }\end{array}$ & \multirow{17}{*}{$\begin{array}{c}\text { Information } \\
\text { and } \\
\text { Communication } \\
\text { Technologies } \\
\text { (Intelligent } \\
\text { Technologies) }\end{array}$} \\
\hline & & \multirow[t]{2}{*}{$\begin{array}{c}\text { Better data } \\
\text { management }\end{array}$} & \\
\hline & \multirow{2}{*}{$\begin{array}{ll}\text { Compliance } & \text { with } \\
\text { government } & \\
\text { regulations } & \text { and } \\
\text { deregulations } & \end{array}$} & & \\
\hline & & \multirow{3}{*}{ Business aliances } & \\
\hline & Ethical issues & & \\
\hline & \multirow[t]{2}{*}{$\begin{array}{l}\text { Terrorist attacks and } \\
\text { homeland security }\end{array}$} & & \\
\hline & & \multirow[t]{2}{*}{ Electronic commerce } & \\
\hline \multirow{7}{*}{ Economic } & $\begin{array}{l}\text { Global economy and } \\
\text { strong competition }\end{array}$ & & \\
\hline & $\begin{array}{l}\text { Need for real-time } \\
\text { operations }\end{array}$ & Strategic systems & \\
\hline & & $\begin{array}{l}\text { Customer focus and } \\
\text { service (CRM), self- }\end{array}$ & \\
\hline & Changing workforce & & \\
\hline & & $\begin{array}{c}\text { Continous } \\
\text { improvement efforts }\end{array}$ & \\
\hline & Powerful customers & $\begin{array}{l}\text { (just-1n-tıme, total } \\
\text { quality management), } \\
\text { KM, ERP }\end{array}$ & \\
\hline & & $\begin{array}{l}\text { Business process } \\
\text { restructuring and }\end{array}$ & \\
\hline \multirow{3}{*}{ Technology } & \multirow{2}{*}{$\begin{array}{l}\text { Technological } \\
\text { innovations and } \\
\text { obsolescence }\end{array}$} & management (BPM) & \\
\hline & & Intelligent data & \\
\hline & Information overload & $\begin{array}{c}\text { On-demand } \\
\text { made-to-order mass } \\
\text { customization } \\
\end{array}$ & \\
\hline
\end{tabular}

Source: K.Rainer, C.G. Cegielski, (2011), Introduction to Information Systems: Enabling and Transforming Business, 3rd edition, John Wiley \& Sons, Inc., New Jersey, p.16-adaptation 
Given the expressed opinions, we can appreciate that an intelligent solution (known also as intelligent application) involves assisting of human in solving problems, using representations of human thought processes.

The ,intelligent systems" term is often used for artificial intelligence applications ${ }^{7}$.

Organized assembly of data and information and all the procedures and instruments for acquisition, processing and transmission of data and information, using artificial intelligence applications to assist users in carrying out their mission, optimizing decision-making, forms an intelligent information system. Depending on the needs of knowledge at different levels of the organization, they may be:

- Intelligent Economical Information Systems;

- Intelligent Management Information Systems;

- Intelligent Decision Support Information Systems;

- Intelligent Information Systems for Strategic Management.

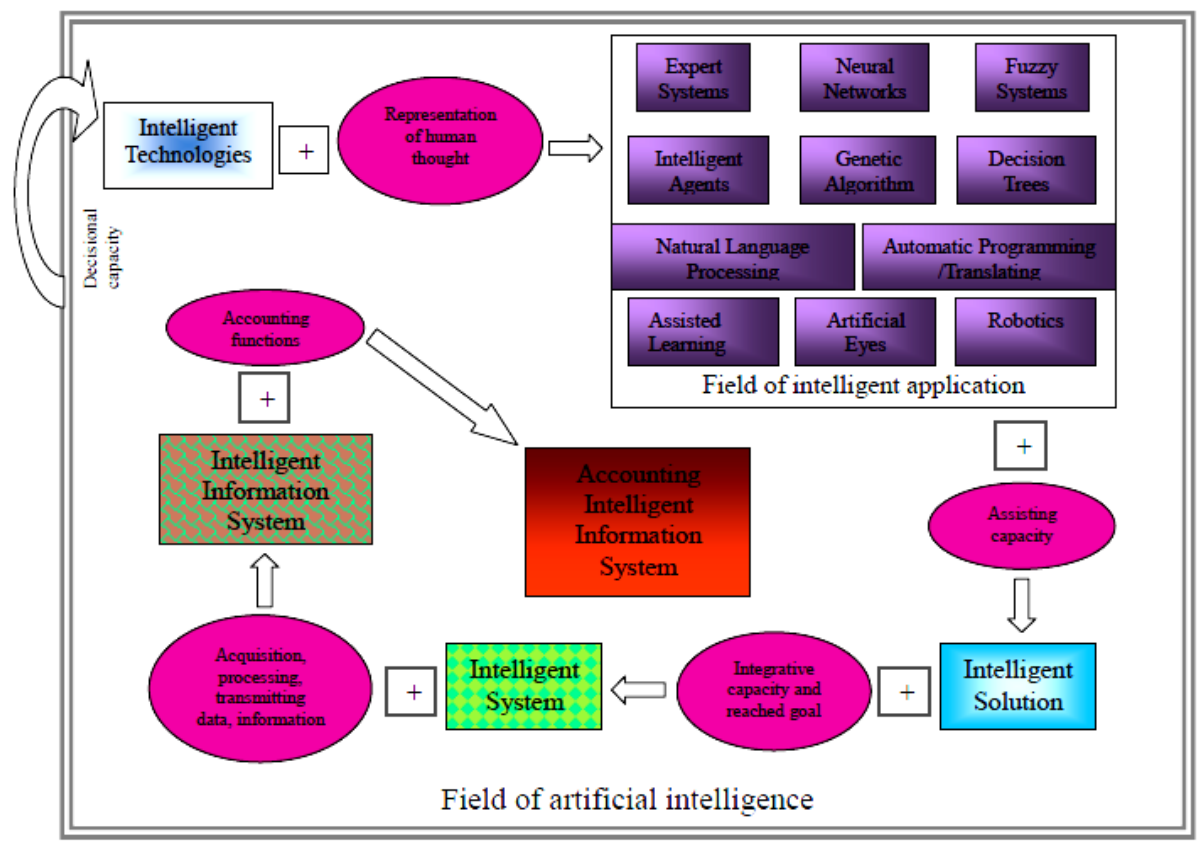

Figure 2. Placement and interrelation of technologies in the field of artificial intelligence systems.

Accounting is an essential component of economic information system, as by specific means and procedures provide:

- clarification of business past and present;

- guidance on future economic strategy;

- relevant analysis facing market;

- limiting field of random decisions;

- solutions and reasons for decisions.

Previous opinions lead us to the following definition of intelligent accounting information system: the organized assembly of data, information and knowledge, along with all the

\footnotetext{
${ }^{7}$ Andone, I., Dologite, D., Mockler, R., Țugui, A.(2001), Dezvoltarea sistemelor inteligente în economie, Economic Publishing House, Bucharest, p.35

${ }^{8}$ Horomnea, E. (2008), Fundamente ştiinţifice ale contabilităţii.Doctrină.Concepte.Lexicon.,Tipografia Moldova Publishing House, Iasi, p. 161
} 
procedures and instruments for acquisition, processing and transmission of data, information and knowledge, using artificial intelligence applications, by the accounting main functions, for assisting the user in order to fulfill its mission, optimizing decision making.

The typology of intelligent accounting information systems can be established in view of the main functions of accounting to substantiate decision making, as follows:

- intelligent accounting information systems for organizing, recording and processing of data, information, knowledge and recommendations regarding economic phenomena and processes;

- intelligent accounting information systems for observation, information, knowledge and learning support;

- intelligent accounting information systems for internal control and audit support;

- intelligent accounting information systems for economic litigations support;

- intelligent accounting information support in forecasting management.

In graphical form, place of presented technologies and systems, within applications of artificial intelligence, and relations between them are shown in Figure 2.

\section{Accounting activities and processes facilitated by intelligent technologies}

According to Myers ${ }^{9}$, in qualitative research, hermeneutics contributes to a profound analysis of social and organizational aspects in management and economics. The author believes that the aim of hermeneutics is to clarify and understand a subject.

The most objective form of hermeneutics is researching the phenomenon from inside, when the subject is familiar to the researcher, who has experience in that area ${ }^{10}$.

From this perspective, we show accounting main activities and processes covered by intelligent technologies.

Accounting activities and processes refers to the creation, organization, use, management and control of accounting information system.

Regarding the establishment of information flow, intelligent technologies can assist the following activities:

- identifying the optimal structure of information flow for a particular type of entity;

- document models selection, according to specific circumstances;

- making recommendations on organizing and archiving of documents; etc.

Establishing optimal methods for collecting and storing data and information provides, to a large extent, the success of the accounting function. With intelligent technology, the following can be achieved more easily:

- providing suggestions for organizing accounting journals, appropriate to each subunit;

- identify the optimal time for storage of documents in each compartment, using a heuristic knowledge base; setting, thus, deadlines for accounting items registration;

- process simulations, for each choice, due the application of different rules of thumb for collecting and storing data;

- conceptual design of consolidation algorithms on financial statements, through execution rules; etc.

In terms of data and information processing, intelligent technologies may contribute in the following ways:

- selection of optimal alternative on the accounting treatment and accounting items, for specific events or documents;

\footnotetext{
${ }^{9}$ Myers, M.D. (2009), Qualitative Research in Business \& Management, Sage Publications Ltd., London, p. 182

${ }^{10}$ Bleicher, J. (1982), The hermeneutic imagination: outline of a positive critique of scientism and sociology, Routledge \& K. Paul, London, p. 71
} 
- using knowledge base to assist employees in acquiring skills on information and data processing, in choosing the correct judgment on atypical analyzes, or about the destination and content of reports;

- uncertainty analysis where data are incomplete, illegible or inaccurate on documents, establishing probabilities and risk level, in terms of accurate image alteration; etc.

Complexity of intelligent technologies for data, information and knowledge reporting is increased, given the wide variety of accounting reports. We can illustrate as follows:

- diagnosis of cash deficit causes and recommending corrective actions;

- consulting and simulations in determining purchasing program;

- scenarios to assist decision to substantiation budget of incomes and expenses;

- knowledge base containing complete explanations and examples of interpretation of International Financial Reporting Standards;

- selective distribution of specific accounting knowledge, to assist correct preparation of current reports;

- evaluation and analysis of employees professional performance in the financial accounting department;

- recommendation of optimal paths of action to achieve management objectives; etc.

In terms of administration, audit and control of accounting information system, intelligent systems succeed in:

- selection of suitable options concerning possible acquisition and transfer of duties, or for employees position, in the information system;

- sensitivity analysis on the impact of information flow changes on information system security;

- assistance in determining penalties for non-compliance in reporting tasks, using case-based reasoning, and collection of previous cases;

- questionnaires and task lists inferred through execution rules, to assist the audit of accounting information system;

- adapting alternative solutions to the specific circumstances of inventories;

- incorporate in financial control the knowledge bases containing appropriate actions, for specific situations; etc.

\section{Conclusions}

Our work emphasizes the importance of using intelligent technologies on accounting activities and processes, bringing in the foreground the wide range of competence of these modern solutions.

In this context, in the Romanian accounting practice, measures should be taken to implement intelligent systems, as: "computerization of processes, introducing new forms of organization, including advanced management techniques"11.

We endorse to these ideas, especially as the international accounting practice brings, undoubtedly, viable solution, for the dynamic and complex context of the current economic environment.

The few issues we have described above lead us to agree with the following opinions: "Accounting, the science of organization measurement, is at a threshold of change. It either substantially changes or becomes irrelevant as an external corporate measurement. " 12

\footnotetext{
${ }^{11}$ Horomnea, E. (2008), Fundamente ştiințifice ale contabilităţii.Doctrină.Concepte.Lexicon., Tipografia Moldova Publishing House, Iasi, p. 205

${ }^{12}$ Vasarhelyi, M.A. (2008), "Evolving Accounting Systems Research with Business Measurement Practice-A Letter from the Editor.", Journal of Emerging Technologies in Account., (5), 1, p. xiii.
} 


\section{References}

1. Andone, I., Dologite, D., Mockler, R., Tugui, A.(2001), Dezvoltarea sistemelor inteligente $\hat{\imath} n$ economie, Economic Publishing House, Bucharest

2. Andone, I., Tabara, N., (2006), Contabilitate, tehnologie şi competitivitate, Romanian Academy Publishing House, Bucharest

3. Bleicher, J. (1982), The hermeneutic imagination: outline of a positive critique of scientism and sociology, Routledge \& K. Paul, London

4. Curtis, G., Cobham, D. (2005), Business information systems: analysis, design, and practice, 5th edition, Pearson Education Ltd., Harlow, UK

5. Ebers, M., Ganter, H.D. (2000), "Strategic Applications of Integrated Information Systems", Business Strategy and Information Technology, Edited by Ewan Sutherland and Yves Morieux, Routledge, London, pp.131-142

6. Hagel III, J., Brown J.S. (2001), "Your Next IT Strategy", Harvard Business Review, Harvard Business Publishing

7. Horomnea, E. (2008), Fundamente ştiinţifice ale contabilităţii.Doctrină.Concepte.Lexicon., Tipografia Moldova Publishing House, Iasi

8. Hutton, C. (1815), A philosophical and mathematical dictionary, Vol. II, Printed by S. Hamilton, Weybridge, Surrey, London

9. Maier, R. (2007), Knowledge Management Systems: Information and Communication Technologies for Knowledge Management, 3rd ed, Springer-Verlag, Berlin

10. Myers, M.D. (2009), Qualitative Research in Business \& Management, Sage Publications Ltd., London

11. Naranjo-Gil, D. (2004), “The Role of Sophisticated Accounting System in Strategy Management", The International Journal of Digital Accounting Research, 4, (8), pp. 125-144

12. Negnevitsky, M. (2005), Artificial intelligence: a guide to intelligent systems, 2nd edition, Pearson Education Ltd., Harlow, UK

13. Nelson, R.R. (2005) Technology, Institutions and Economic Growth, Harvard University Press

14. Patrut, V., Rotila, A., Ciuraru-Andrica, C., Luca, M. (2009), "Accounting - a semiotic process", The Annals of the University of Oradea. Economic Sciences, XVII, (III), pp.1105-1112

15. Poole, D., Mackworth, A. (2010), Artificial Intelligence: Foundations of Computational Agents, Cambridge University Press, New York.

16. Rainer, K., Cegielski C. G. (2011), Introduction to Information Systems: Enabling and Transforming Business, 3rd edition, John Wiley \& Sons, Inc., New Jersey

17. Vasarhelyi , M.A. (2008), "Evolving Accounting Systems Research with Business Measurement Practice-A Letter from the Editor.", Journal of Emerging Technologies in Account., (5), 1

18. Warren, C.S., Reeve J.M., Duchac, J. (2012), Accounting, 24th edition, Cengage Learning, Mason, USA

19. Weetman, P. (2006), Financial accounting: an introduction, 4th edition, Pearson Education Ltd., Harlow

20. Zack, M.H., (2002), "Developing a Knowledge Strategy", In: C. W. Choo and N. Bontis, eds., 2002, The strategic management of intellectual capital and organizational knowledge, Oxford University Press, New York, pp. 255-276. 